О.І.ГАПОНЮК, Д-р техн. наук, професор, зав. кафедри технологічного обладнання зернових виробництв, О.В. АЛЕКСАШИН, канд. техн. наук, доцент, М.І. ВІЛЬЧИК, студент, С.В. КОЛОСОВСЬКИЙ, студент Одеська начіональна академія харчових технологій, м. Одеса

\title{
ОПТИМІЗАЦІЯ РЕЖИМУ ОХОЛОДЖЕННЯ ГРАНУЛЬОВАНИХ КОМБІКОРМІВ
}

В даній статті розглянуті иляхи забезпечення необхідної якості гранульованого комбікорму при його охолодженні, зменшення енергетичних витрат. Наведено основні параметри, які суттєво впливають на проиес охолодження гранул комбікорму після просіювання, показані причини виникнення недоліків при отриманні готового продукту. Розглянуто приничи розподілу повітряних потоків при охолодженні гранул в охолоджувальних колонках, виділені критерії для їх порівняльної характеристики. На підставі експериментальних досліджень виконані розрахунки оптимальної температури повітряного потоку спрямованого на охолодження гранул, визначені енергетичні характеристики прочесу охолодження, наведено рекомендаиії технічної реалізацї забезпечення необхідної якості готового продукту. Показано, щзо величину витрати повітря, шуо подається в охолоджувальну колонку для охолодження гранул можна істотно зменшити, забезпечити стабілізачію температури повітря на певному рівні. При изому, недостатнє охолодження призводить до появи мікротріщцин на поверхні гранул, щчо знижує їхню твердість, збільщує вміст пилу, сприяє конденсації вологи, щзо призводить до появи бактерій, ињвілі і виникненню процесів гниття. Крім иього, на якість гранул впливають сили тертя в середині охолоджувача, а також діючі напруження зсуву, які виникають при роботі розвантажувального пристрою. Приведені схеми руху повітря для охолодження. Розглядаючи охолоджувачі з перехресним потоком повітрявідзначено збільшення його витрат на охолодження гранул для забезпечення їхноӥ кінцевої температури. В протитокових охолоджувачах потрібна менша витрата повітря для охолодження, але різниия між початковою і кінцевою температурою продукту незначна. Зміна температури гранул відбувається в прямо пропориійній залежності, а зміна вологості відбувається при менших швидкостях повітряного потоку. Враховуюче проведені дослідження, а також у залежності від типу охолоджувальной колонки та технологічної лінії гранулювання комбікормів, запропоновано ряд рекомендачій по застосуванню засобів клімат-контролю, запропоновані иляхи автоматичного управління прочесом охолодження гранул.

Ключові слова: охолоджувальна колонка, гранульований комбікорм, температура повітря, режим охолодження.

1.Загальна постановка задачі дослідження.

На процес охолодження гранул після пресування, в основному, впливають такі параметри:

- температура повітря, використовуваного для охолодження;

- вміст жиру в гранулах;

- вологість охолоджуваного повітря.

При цьому, температура гранул після охолодження залежить від температури охолоджуючого повітря, що забирається з приміщення, в якому встановлений охолоджувач [1].

В залежності від кількості яка додається у гранули жиру в процесі охолодження потрібен великий розхід охолоджуючого повітря і збільшення часу охолодження.

Недостатнє охолодження призводить до появи мікротріщин на поверхні гранул, що знижує їх твердість, збільшує вміст пилу, сприяє конденсації вологи, що приводить до появи бактерій, цвілі і виникненні процесів гниття.

Усередині охолоджувача на якість гранул впливають такі чинники:

- взаємодія гранул один з одним з урахуванням взаємного тертя;

- зовнішні сили (діючі напруги зсуву), що виникають при роботі розвантажувального пристрою охолоджувача.

Застосовувані в комбікормовій промисловості охолоджувачі залежно від напрямку руху охолоджуючого повітря бувають наступні [2]:

- 3 перехресним потоком охолоджуючого повітря (рис. 1.1);
- проти точні (рис. 1.2).

Якщо порівняти зазначені принципи охолодження, то доцільно виділити наступні критерії:

- витрата охолоджуючого повітря;

- різниця температур продукту і охолоджуючого повітря;

- потік охолоджуваних гранул.

Розглядаючи охолоджувачі з перехресним потоком охолоджуючого повітря, слід зазначити збільшення витрати подаючого для охолодження гранул повітря для забезпечення кінцевої температури. У протиточних охолоджувачах потрібна менша витрата охолоджуючого повітря, однак різниця між початковою і кінцевою температурою продукту незначна. При цьому зміні температури гранул виникає в прямо пропорційній залежності, а зміни вологості виникає при менших швидкостях повітряного потоку.

3 урахуванням того, що у вітчизняній комбікормової промисловості застосовуються, в основному, охолоджувачі з перехресним потоком охолоджуючого повітря, доцільно визначити його оптимальні параметри.

\section{2. Експериментальні дослідження.}

Завдання досліджень сформульована як забезпечення мінімуму енергетичних витрат при необхідній якості гранул (розкришуваність, вологість) в процесі їх охолодження.

На підставі проведених експериментальних робіт, виконаних в умовах Київського комбікормового заводу [2], сформульовані наступні напрямки:

- визначення температурного режиму охолод- 


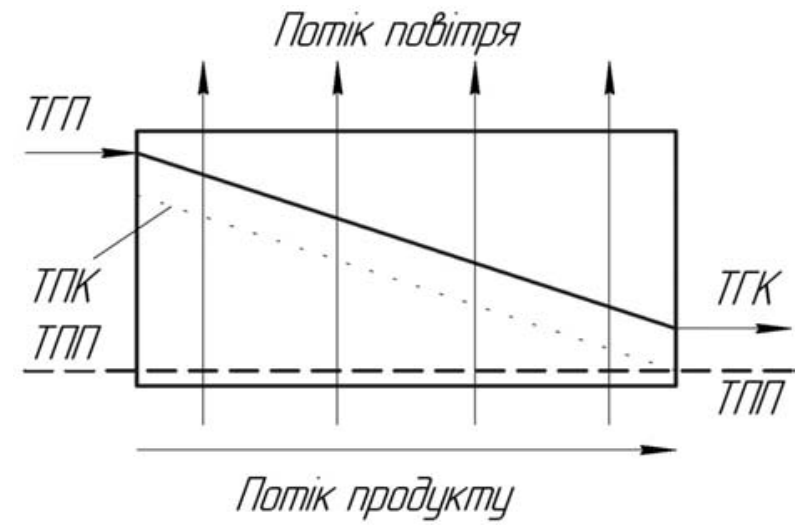

Рис. 1 - Принцип роботи охолоджувача 3 перехресним потоками охолоджуючого повітря:

ТГП - температура гранул початкова;

ТПП - температура повітря початкова;

ТПК - температура повітря кінцева;

ТГК - температура гранул кінцева

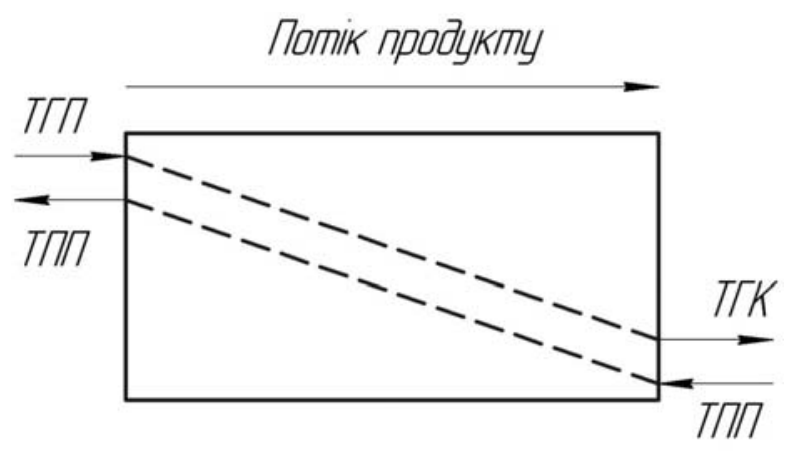

\section{Пomik повітря}

Рис. 2 - Принцип роботи протиточного охолоджсувача

ТГП — температура гранул початкова;

ТПП - температура повітря початкова;

ТПК - температура повітря кінцева;

ТГК - температура гранул кінцева

жуючого повітря гранульованого комбікорму;

• визначення площі поверхні гранул для відводу тепла;

- визначення часу знаходження (експозиції) гранул в охолоджувальній колонці.

За першим напрямком задачею розрахунку $\epsilon$ визначення значень температури повітря, що подається в охолоджувач, з урахуванням того, що температура готового продукту не повинна перевищувати температури навколишнього середовища більше ніж на $10^{\circ} \mathrm{C}$.

Продуктивність охолоджувача по сухій речовині становить:

$$
\Pi_{\mathrm{KC}}=\frac{\Pi_{\mathrm{TK}}\left(100-\mathrm{W}_{\mathrm{TR}}\right]}{100}
$$

де: $\mathbb{I}_{I \aleph}-$ продуктивність охолоджувача по готовому продукту , кг/с;

$W_{\text {тs }}$ - вологість гранул, кінцева, \%.

Продуктивність охолоджувальної колонки за питомою вологою:

$$
\Perp_{\mathrm{kg}}=\Perp_{\mathrm{kr}}-\Perp_{\mathrm{kr}} \text {, }
$$

Затрати енергії, необхідних для охолодження гранул:

$$
\mathrm{N}_{\mathrm{ow}}=\Pi_{\mathrm{kK}} \mathrm{C}_{\mathrm{kM}}\left(t_{\mathrm{kH}}-t\right),
$$

де: $\mathrm{C}_{\text {ға }}$ - теплоємність сухої маси гранул в од-

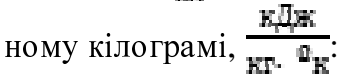

$$
C_{\mathrm{Kr}}=\frac{\mathrm{c}_{\mathrm{rv}}}{\gamma_{\mathrm{rk}}}
$$

$t_{\text {кн }}$ - температура гранул, що подаються 3 пресу-гранулятора, " $\mathrm{C}$; дження

$t_{\mathrm{sk}}$ —кінцева температура гранул після охоло-

Затрати енергії, необхідні для видалення вологи:

$$
\mathrm{N}_{\mathrm{yI}}=r \Pi_{\mathrm{Kg}} \text {, }
$$
ги, Дж/кг;

де: r- прихована теплота пароутворення воло-

Затрати енергії, необхідні для відведення повітря:

$$
N_{\mathrm{g}}=N_{\mathrm{ox}}-N_{\mathrm{yg}},
$$

При встановленому вентиляторі певної продуктивності, температура повітря, подаваного для охолодження, необхідного для забезпечення технологічних умов складе:

$$
t_{\mathrm{gH}}=\frac{t_{\mathrm{n}}}{3600 \mathrm{C}_{\mathrm{n}} \mathrm{V}_{\mathrm{z}} s_{\mathrm{g}}},
$$

де: $\mathrm{V}_{\mathrm{g}}$ - продуктивність вентилятора, $\mathrm{M}^{2} / \mathrm{rog}$,

$t_{\mathrm{z}}$ - температура повітря в приміщенні, ${ }^{\circ} \mathrm{C}$,

$\mathrm{C}_{\mathbf{z}}$ - теплоємкість повітря кДж/кг• ${ }^{\star}$, рівна 1,0 .

Якщо забір повітря здійснюється 3 приміщення, в якому знаходитися охолоджувальна колонка i температура повітря при цьому вище ніж $t_{\text {q }}$, то необхідного охолодження гранул не відбувається.

Якщо температуру яка подається в охолоджувальну колонку повітря встановити на рівні, наприклад 10 들, то його витрату можна зменшити приблизно в два рази:

$$
V_{\mathrm{s}}=\frac{N_{\mathrm{n}}}{\mathrm{C}_{\mathrm{a}}\left(\mathrm{t}_{\mathrm{n}}-\mathrm{t}_{\mathrm{aH}}\right)}
$$

Таким чином, для забезпечення необхідної температури готового продукту, температуру повітря, що подається в охолоджувальну колонку необхідно підтримувати на певному рівні. 
Що стосується визначення площі поверхні гранул для відводу тепла та експозиції їх охолодження, то дані напрямки залежать від конструктивних особливостей охолоджувальних колонок і можуть бути розглянуті в окремих конкретних випадках.

\section{3. Висновки і рекомендації.}

Згідно 3 наведеними розрахунками визначені наступні шляхи модернізації процесу охолодження гранул комбікорму:

- температура повітря, що подається в охолоджувальну колонку, повинна відповідати певному значенню $(15-16)^{\circ} \mathrm{C}$;
- витрата повітря для охолодження гранул можна значно зменшити (приблизно до 30\%), що приведе до скорочення витрат на електроенергію на $18-20 \%$;

- залежно від типу охолоджувальної колонки, застосовуваної у відповідній лінії гранулювання комбікормів, можна запропонувати одну 3 установок клімат-контролю фірми RHOSS [3] та обладнання[4];

- мінімально необхідний контроль температури потрібно здійснювати у двох точках - на вході подачі повітря в охолоджувальну колонку і на виході готових гранул і відповідно управляти системою охолодження в автоматичному режимі.

\section{СПИСОК ЛІТЕРАТУРИ}

1. Правила організації і ведення технологічного процесу виробниџтва комбікормової продукції.-Міністерство АПК України, Київ, 1998, 202 стор.

2. Разработка системы контроля и управления теплом - и влагосъеом гранулированного комбикорма в процессе его охлаждения: Отчет о НИР / ОГАПТ им. М.В. Ломоносова. - Научный руководитель д.т.н., профессор Дмитрук Е.А. Oдесcа, - 1996.-64c.

3. RHOSS CLIMA EVOLUTION. - www.rhoss.com .

4. ОАО “Докон”. - Домодедовскиймашиностроительный завод "Кондиционер" http://www.docon.ru, E-mail: mail@donor.ru.

\section{OPTIMIZATION OF COOLING GRANULAR FODDER}

This article discusses ways to ensure the necessary quality granulated feed during its cooling, reducing energy costs. The main parameters that significantly affect the cooling process after the screening of feed pellets, shows the causes of deficiencies in the delivery of the finished product consideration of the principle of distribution of air flow during cooling granules in the cooling tower, marked signs for their comparative performance. On the basis of experimental studies made calculations optimal airflow temperature aimed at cooling the pellets, determined the energy characteristics of the cooling process, provides guidance to ensure the technical realization of the desired quality of the finished product. It is shown that the flow rate of air supplied to the pooling tower to cool the granules can be substantially reduced to stabilize the temperature of the air at a certain level. Thus, insufficient cooling leads to the appearance of microcracks on the surface of the granules, which reduces their hardness increases the amount of dust, promotes the condensation of moisture, which leads to the emergence of bacteria, mold and rot. In addition, the friction force inside the cooler affects the quality of the pellets, as well as the existing shear stress occurring during operation of the discharge device. Shown diagrams illustrating the movement of cooling air. Considering coolers with crossflow cooling air marked increase its flow rate for cooling the granules to provide the final temperature. In counterflow coolers require a smaller amount of cooling air, but the difference between the initial and final temperature of the product is low. Changing the temperature of the pellets takes place in a direct proportional relationship, and the change of humidity occurs at lower air flow velocities .

Keywords: cooling granular feed column, the air temperature, the cooling mode.

\section{REFERENCES}

1. Rules of organization and conduct of the process of production of animal feed produktsiyi.-Ministry of agriculture of Ukraine, Kyiv, 1998, 202 p.

2. Development of systems of control and management of heat - and vlahosbeom hranulyrovannoho kombykorma ego in the process cooling: Otchet at NYR / OSAFT. University. - Nauchny Leader Ph.D., Professor E.A. Dmitruk. Odessa - 1996.- 64 p.

3. RHOSS CLIMA EVOLUTION. - www.rhoss.com .

4. http://www.docon.ru, E-mail:mail@donor.ru.

Надійшла 23.05.2014

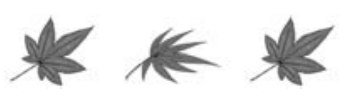

